Hayek Shrugged: Why Bureaucracy Didn't Die Under Neoliberalism But Boomed Instead

\author{
Peter Fleming \\ (peter.fleming@uts.edu.au) \\ University of Technology Sydney \\ 14-28 Ultimo Rd \\ NSW 2007, Australia
}




\title{
Hayek Shrugged: Why Bureaucracy Didn't Die Under Neoliberalism But Boomed Instead
}

\begin{abstract}
Commentators have observed how neoliberal capitalism - contrary to the official narrative frequently correlates with enthusiastic bureaucratisation, and perhaps has done so from its inception. Despite this acknowledgement, the precise mechanisms involved remain obscure. Focusing mainly on the writings of F.A Hayek, I argue that economic libertarianism is often contingent on a particular spirit of administration, justification for which can be found in the 'fine print' of Hayek among others. Furthermore, this counterintuitive symbiosis is realised through three institutional mechanisms, fuelling bureaucratisation in ostensibly pro-market environments. I discuss these mechanisms before exploring the implications they have for opposing the present economic regime.
\end{abstract}

KEY WORDS: Authoritarianism; bureaucracy; Class antagonism; Chicago School of Economics; F.A. Hayek; Neoliberal Capitalism

I.

One of the more noticeable contradictions between the avowed ideals of neoliberalism and its practical application in society is the persistence of bureaucracy. Of course, neoliberal thought (as articulated by an unending phalanx of theoreticians, policy analysts and politicians over the last forty years) is not a homogeneous discourse. ${ }^{1}$ Nevertheless, there is perhaps one theme that does unite F.A Hayek, George Stigler, Milton Friedman, James M. Buchanan and the so-called Chicago School: their hatred of bureaucracy. The vapid bureaucrat, who is normally conflated with 'big government' and its ready-supply of paperwork, is said to thwart entrepreneurship and the spontaneous order of the marketplace. Any well-functioning capitalist economy should therefore keep their numbers to a bare minimum.

And yet there's an elephant in the room.

Even a cursory glance at societies that have undergone neoliberalisation show them replete with formidable bureaucracies, in both the public and private sector. We could demonstrate this quantitatively, using civil service spending data, for example, as a proxy for governmental administration. Statistics concerning the consolidation of capital into 'super-companies' tell a similar story regarding the probable density of bureaucracy in the private sphere. While these 
figures are important for gauging its scope today, the qualitative nature of bureaucratisation must be considered also. Whether numerically big or small, I propose, bureaucracy has thrived under neoliberalism - even as it enters into crisis - for one basic reason: to defend and advance the interests of the business elite, often assuming a punitive stance to do so. It's the penalising tone that makes the qualitative difference, accentuating the feeling that we're being constantly regulated by heartless functionaries, despite the ongoing evisceration of social services and the welfare state. Small can sometimes mean 'big' in this respect.

The disconnect between the idealisation of deregulated capitalism and the goliath-like administrations surrounding us today is striking and worthy of careful explanation. Towards this end, David Graeber posits the 'iron law of liberalism', arguing that 'financialisation, violence, technology [and the] fusion of public and private' links the double-truth of market worship on the one hand and 'total bureaucratisation' on the other. ${ }^{2}$ According to Béatrice Hibou, bureaucracy in the neoliberal age follows the disciplinary formalisation of everyday life. $^{3}$

Graeber and Hibou's observations are useful but remain vague about the exact mechanisms involved. It's not enough to simply say that markets require top-down orchestration, particularly given how economic libertarianism and big bureaucracies are officially meant to be miles apart. Hence the purpose of this paper. As a mode of economic governance, neoliberalism is reliant on a certain spirt of bureaucratisation. We can identify signs of this in the 'fine print' of the theory itself (qualifications concerning corporate monopolies, an intrusive administrative state, etc.) and the obvious institutional requirements that its practical realisation necessitates in the social domain. I want to go further, however. What are the exact mechanisms that marry the ostensibly opposing logics of neoliberal reason and bureaucracy today? Three will be discussed: a) the concentration/centralisation of corporate and finance capital, b) the erosion of labour's position of power vis-à-vis employers and c) the reformulation of statecraft into a conspicuously repressive process, typically in the name of economic discipline.

II.

As Max Weber showed, modern bureaucracy emerged in several locations around Europe in the late $18^{\text {th }}$ Century, modelled after the Chinese system. ${ }^{4}$ Boiled down to its essential components, bureaucracy differs from previous types of administration (e.g., prebendal custom and patronage, kadi-justice, etc.) given the unusual formalism it exhibits. This stems from the calculative use of records, standardised rules, obedience to legal-rational authority and the 
minimisation of favouritism via the Tacitean code of sine ira et studio ("without anger or fondness'). ${ }^{5}$

Weber viewed the spread of bureaucracy as inevitable given its superior efficiency and planning capabilities, both in business and government. But he was famously ambivalent about whether that was a good thing. Regardless, it wasn't long before bureaucracy was being criticised from all sides for it dehumanising effects. Sure, soviet communism was a major target, but plenty of attention was paid to capitalist societies too. Left-wing thinkers like C. Wright Mills, Herbert Marcuse and Ivan Illich inveighed bureaucracy from this perspective. ${ }^{6}$ They uncovered its connexion with class control in the post-war period, where 'domination is transfigured into administration'. ${ }^{7}$

Criticisms by right-wing neoclassicists are of more interest to us since they were central to the restitution of laissez faire capitalism from the 1980s onwards. Although by no means homogeneous or without disagreement, an almost mythic distrust of the state is a common denominator in this intellectual tradition. The state meant many things to F.A Hayek, Frank Knight, Milton Friedman, George Stigler and Gary Becker inter alia, but a centralised bureaucratic complex was first and foremost.

So what is neoliberalism? David Harvey defines it as follows:

Neoliberalism is in the first instance a theory of political economic practices that proposes that human well-being can best be advanced by liberating individual entrepreneurial freedoms and skills within an institutional framework characterised by strong private property rights, free markets and free trade... if markets do not exist (in areas such as land, water, education, health care, social security, or environmental pollution) then they must be created, by state action if necessary. But beyond these tasks the state should not venture. State interventions in markets (once created) must be kept to a bare minimum because, according to the theory, the state cannot possibly possess enough information to second-guess market signals (prices) and because powerful interest groups will surely distort and bias state interventions (particularly in democracies) for their own benefit. ${ }^{8}$

The state is prominent in this definition, but principally as a negation. ${ }^{9}$ By default, the market stands for 'the nonstate' and vice versa, a rather simplistic dualism for sure given how governments are also dominant market actors. 
Neoliberal theoreticians conflated bureaucracy with the state for several reasons. Despite examining business administration in detail, Weber's main inspiration was the Prusso-German civil service. The consequences that bureaucratisation had for mass democracy also preoccupied his thinking. Moreover, Weber's influential student Robert Michel's used political parties to illustrate his 'iron law of oligarchy', claiming that even the most democratic organisations will develop an insulated and autocratic apex. This cynical view no doubt influenced Public Choice Theory as well, a branch of neoclassical economics (e.g., William Niskanen, James M. Buchanan, etc.) that views government officials as selfish rent-seekers. Finally, we shouldn't omit the spectre of Soviet communism in compounding these unsympathetic views.

At any rate, this state-phobia effortlessly transitions into a distrust of bureaucracy, constructing a zero-sum game between a) the innovative entrepreneur who creates wealth and jobs on the one hand and b) the obstructive government official who taxes them on the other. We could identify many examples to illustrate this 'markets vs hierarchies' dichotomy, but I'll concentrate on F.A Hayek since his libertarianism is frequently read this way. Even though Hayek was never hired by the Chicago School of Economics (a professorship was created for him in the Committee of Social Thought in 1950) and he resisted the mathematisation that would later define neoclassicism, by the early 1980s followers and detractors alike believed he best summed up the intellectual arm of neoliberalism. But here's the rub. Even in Hayek's uncompromising stance, I argue, can be detected implicit qualifications and exceptions that are remarkably conducive to a certain variant of bureaucratisation in the public and private sphere. Furthermore, perhaps it is here that the intellectual roots of today's authoritarian capitalism can be found too, suggesting not the demise of neoliberal doxa but a perverse and sometimes bizarre over-manifestation of it.

\section{III.}

The book that made Hayek famous, The Road to Serfdom, was published in 1944 with an abridged version appearing in the American magazine, Readers Digest. The book conveys many of the ideas he gleaned from his mentor Ludwig Von Mises, who himself penned a cantankerous tract about socialist governmentality called Bureaucracy in $1944 .{ }^{10}$ Hayek claims that the road to political backwardness is paved by central planning and state intervention in economic affairs. It wasn't a wayward corporate sector that spawned totalitarianism - the conventional wisdom among intellectuals during World War II influenced by Daniel Guérin 
among others - but collectivism per se. ${ }^{11}$ Therefore, even relatively liberal democratic sovereignties informed by Keynesian planning, for example, could easily slide in this direction according to Hayek. Whereas a society built almost entirely on an open marketplace permits businesses and individuals to voluntarily compete, requiring little central authority. The 'price signal' alone coordinates their activities, communicating information from innumerable actors in a spontaneous and non-coercive manner. What Hayek would later term catallaxy refers to, 'order brought about by the mutual adjustment of many individual economies in a market' ${ }^{12}$ Government planners cannot achieve the same level of coordination due to their limited capacity to gather and process the necessary information.

In The Road to Serfdom, Hayek treats bureaucracy as a synonym for state planning, diametrically opposed to private enterprise, which wilts under the yoke of centralised command: "where the scope of the political measures becomes so large that the necessary knowledge is almost exclusively possessed by the bureaucracy, the creative impulses of the private person must flag'. ${ }^{13}$ This gives state officials undue control over citizens and is anathema to personal liberty. An objection might be raised here, however, concerning unequal power relationships in the private sector, say between employer and employee. Aren't they just as problematic? No says Hayek because workers are always free to quit: 'who can seriously doubt that the power which a millionaire, who may be my employer, has over me is very much less than that which the smallest bureaucrat possesses who wields the coercive power of the state and on whose discretion it depends how I am allowed to live and work? ${ }^{14}$ For Hayek writing in The Road to Serfdom, only a night watchman state ensuring basic rule of law is advisable in a free society.

Here's my basic argument. Hayek's libertarian social philosophy will undergo substantial modifications and qualifications in the decades following The Road to Serfdom. For instance, his anti-state purism is quietly tempered in The Constitution of Liberty published in 1960. Governments are still the ultimate vehicle of bureaucratisation since they are primarily rule/law makers, necessitating administration and enforcement. But something strange also happens. In the 'fine print' of his discourse, Hayek quietly admits that a strong state is not always detrimental to commercial freedom. Neoclassical economists have been confused on this score according to Hayek, since the state can do much more than just safeguard law and order:

$\ldots$ it is the character rather than the volume of government activity that matters. A functioning market economy presupposes certain activities on the side of the state; there 
are some other such activities by which its functioning will be assisted; and it can tolerate many more, provided that they are of the kind that are compatible with a functioning market. ${ }^{15}$

Indeed, a 'comparatively inactive' state can be just as harmful as a tyrannical one in Hayek's eyes. The criteria for differentiating between desirable and undesirable statecraft is coercion. Rules and policies that 'assist' and 'service' business activity (whether at the individual, corporate or industry level) are commendable. Those that force firms to act as they otherwise would have (particularly in the name of 'distributive and social justice') are lamentable because economic agency is stifled. ${ }^{16}$ It's easy to see why Margret Thatcher reputedly fell in love with The Constitution of Liberty, even though she was probably more aligned with Milton Friedman's monetarism. A new pragmatist tone enters Hayek's theorising, albeit on the margins. To keep society on the true path a definite activation of the state is needed, no less intrusive than its Keynesian counterpart; one that defends business and chides welfare and unions; furthers free trade, maintains favourable conditions for entrepreneurship and so-on.

This theoretical modification explains Hayek's surprising sympathy for the economic federalisation of Europe, which would require central planning and administration in order to run smoothly. It's the way governmental bureaucracy is used (flowing from Brussels as it would happen) that is decisive. As long as it promotes the free movement of capital, debt and labour, an integrated union would be commensurate with the tenets of neoliberalism. ${ }^{17}$ On a different - but as we'll soon see, not necessarily disassociated - dimension, Hayek's adulation for the Pinochet coup in Chile is also telling. The blending of free market reforms with tranny was 'absolutely fantastic'. ${ }^{18}$

The arguments in The Constitution of Liberty can therefore be distinguished from the anti-state zealots who emerged in Hayek's wake, like Murray Rothbard and Anthony De Jasay. Nor was Hayek simply rehashing Wilhelm Röpke's German Ordoliberalism (where state intervention is used to nurture free competition). This becomes apparent with some additional qualifications that Hayek makes apropos his earlier libertarianism, this time concerning corporate monopolies and their valorisation in neoclassical economics. The vacillation is fascinating because large company monopolies/oligopolies are notoriously bureaucratic and patently inimical to competition. While Hayek once eagerly supported the deconsolidation of big business, The Constitution of Liberty is more ambivalent. He begins by maintaining that labour union monopolies are far more reprehensible than their corporate counterparts. Appertaining 
to the latter, he 'has become increasingly sceptical about the beneficial character of any discretionary action of government against particular monopolies, and I'm seriously alarmed by all policy aimed at limiting the size of enterprise'. ${ }^{19}$ For Hayek, it's an 'unpleasant fact of life' that some private monopolies are unavoidable because they're simply better than their competitors. Hayek then swiftly returns to the evils of trade associations, which for him are the real enemy, a perspective repeated twenty years later in the third volume of Law, Legislation and Liberty. ${ }^{20}$

In summary, then, on the fringes of Hayek's ultra-free market philosophy are certain qualifications and exceptions that subsequently allow the key benefactors of neoliberal capitalism to enjoy a number of notable antinomies, thus having their cake and eating it too. An imposing state apparatus, but one that mainly bolsters the interests of private enterprise. A society that venerates unregulated market competition and monetary individualism, but also permits large firms to dominate entire industries in energy, transport, defence, information technology and so-forth. Thus taking into account these escape clauses in Hayek's writing, it's not that surprising to see bureaucratisation thriving in the public and private sectors today.

This makes the political Right's continuing rally cry against bureaucracy even more disingenuous. Take the case of Steve Hilton, onetime advisor to former UK prime minster David Cameron and author of the best-selling tirade against bureaucracy, More Human. ${ }^{21}$ In his quest to rejuvenate Hayekian entrepreneurship in Britain, Hilton created the 'red tape challenge', which intended to rid 21,000 regulations from the economy, with paid maternity leave and building safety regulations at the top of the list. Hilton derided corporate monopolies too. They renounce the magic of competitive enterprise and cause widespread unhappiness. This is where left-wing critics get it wrong, according to Hilton. Capitalism isn't the problem, 'it's the transformation of business into bureaucracies, practically part of the government, writing their own laws, writing their own rules'.22

Given the dispensations we have uncovered in the marginalia of F.A Hayek, Hilton's plea appears to be peddling a kind of kindergarten version of neoliberalism. For sure, one wonders whether Hayek would be that perturbed by the trends Hilton disparages as unfaithful to the capitalist cause. Large government bureaucracies supporting the corporate sector, issuing tax cuts, vilifying unions and subsiding low-wage jobs? Bulky private monopolies and oligopolies controlling whole sectors of the economy, many of which were previously state owned? Rather than being outraged by the scenario, there's a good chance Hayek would merely shrug. 


\section{IV.}

Due to the messy socio-political conditions encountered on the ground, one reason why bureaucratisation is tacitly adumbrated in Hayekian thought comes down to pragmatic expediency. As long as the administrative machine is poised in favour of business, it's acceptable. The assumption underwrites tendencies that exemplify how capitalism has evolved in recent times. These can be analysed with respect to three institutional mechanisms, all of which are coextensive with today's burgeoning public and private bureaucracies.

The first concerns the concentration/centralisation of corporate and finance capital, which in turn stimulates the growth of administrative systems relating to managerialism, regulated accumulation, contractualisation and so-on. We're all familiar with the official narrative. An economy populated with freely competing private businesses, compelled to become efficient and responsive to customers, is infinitely more desirable that central planning by 'big government' and its throng of technocrats. As von Mises declared, the profit-motive keeps firms nimble while state bureaucracies display inertia: 'no private enterprise will ever fall prey to bureaucratic methods of management if it is operated with the sole aim of making profit., ${ }^{23}$ The reality of neoliberal capitalism - from the 1980s onwards - has been very different. A prominent aspect of Western economies is the tremendous concentration (growth in the size of individual businesses) and centralisation (fewer players controlling specific industries) of capital. The concept of monopoly capitalism isn't new, of course. ${ }^{24}$ But its reinvigoration by international financialisation is, where a semi-cartelisation process has created 'super companies' that dominate global markets, often in alliance with powerful state actors. ${ }^{25}$ Research has found that 147 of the largest firms now control 40 per cent of the global wealth network. ${ }^{26}$ Another study focused on 'waves' of corporate amalgamation in the US economy since the 1880s. The latest wave (2000-present) is propelled by the deregulation of mergers and acquisitions and a fresh focus on international money markets (including 'shadow banking'). The outcome is startling. There are about 5.7 million registered corporations in the US, but one-fifth of total assets are owned by only $100 .^{27}$

Monopolistic and oligopolistic tendencies latent in capitalism gain momentum when business corporations are comparatively self-regulating and declining rates of return make competition undesirable. The consolidations that develop, however, don't necessarily contradict neoclassical principles because private monopolies are implicitly condoned. This begins with 
the influence of Aaron Director (Head of the Chicago School of Law) and his criticism of antitrust legislation (i.e., the Sherman Act 1880 and Clayton Act 1914). Director convinced colleagues at the School of Economics that corporate syndicalisation is justifiable if it leads to socially beneficial outcomes. This explains why founding Chicago School economist Frank Knight subsequently complained that,

... the public has most exaggerated ideas of the scope of monopoly as really bad and remediable, and talk of "abolishing" it is merely ignorant or irresponsible. There is no clear line between legitimate and necessary profit and the monopoly gain that presents a problem for action. ${ }^{28}$

Erstwhile defenders of antitrust legislation like Milton Friedman would soon see the light, chastising the US government's attempt to break up Microsoft in the late 1990s (culminating with United States v Microsoft 2001). For Friedman, this discourages firms to be the best in their respective industries. ${ }^{29}$ Labour monopolies on the other hand were a totally different matter. $^{30}$

The link between corporate monopolies/oligopolies and bureaucratisation has long been noted, especially concerning the colossal conglomerations that characterised Fordism. ${ }^{31}$ Business historian Alfred Chandler claimed that if early US capitalism typified the 'invisible hand' of market pluralism (where small enterprises vie with each other in a Jacksonian milieu) then the $20^{\text {th }}$ Century was marked by a 'visible hand', with an army of bureaucrats running complex multiunit companies. ${ }^{32}$ The same applies today, albeit focused through the lens of neoliberalisation. For instance, business bureaucratisation is especially evident when large companies take over from where government left off as the public sector is pared-down and/or privatised. ${ }^{33}$ The provision of mass goods and services, especially when users are dependent on a provider, sees corporate administration truly bloom. This distinguishes firms that enjoy a monopoly in exclusive markets, say a luxury yacht manufacturer with a limited number of wealthy clients, from ones that control water and sewerage services in a metropolis like London. Here bureaucratisation reflects a) the size of operations (e.g., multiplying managerial hierarchies inside the firm), b) the need for legal-rational expertise pertaining to said operations (e.g., use of lawyers, tax accountants, contract and patent experts, etc.) and c) the technical challenges of extracting the greatest surpluses from dependent customers.

But again, the number of bureaucrats tell us only half the story. The centralisation of corporate activity more generally has created administrative forms of a specific ilk, displaying qualitative 
differences that override the volume involved. As F.A Hayek himself said, 'character' is of utmost importance. Three characteristics standout when it comes to neoliberal business administrations. The first pertains to supervision. As the rate of profit steadily declined between the 1970s and 1990s and then stagnated to the present, the internal administration of labour was intensified. Micromanagement was soon all the rage and unemployment the whip. Close quarters control of workers isn't new either, but it took on fresh urgency following the collapse of the labour/capital compact during the Thatcher/Reagan period. ${ }^{34}$ After management gained the upper hand, seeking unit-labour cost efficiencies and extra effort, corporate bureaucracy took on the retributive flavour that is commonplace today (e.g., Human Resources, etc.).

The second characteristic relates to regulating external stakeholders that present risks and opportunities to the monopolistic arrangement. Stakeholders include government policy/lawmakers, business partners and investors, lobbying organisations, disgruntled neighbourhood groups, shareholders and potential rivals. Moreover, legal and contractual services take on greater importance in these firms because of their market/industry dominance: competition and intellectual property law, litigation, mergers and acquisitions, compliance, tax liability strategies all need to be superintended by trained experts, either in house or through agencies.

The third quality concerns the extractive relationship these corporate bureaucracies maintain with its captive customer-base. They're designed to maximise exploitation (e.g., the use of penalty fees, measures to prevent goods and services entering the black market, disincentivising refunds, etc.), standardise the customer interaction process to save costs (e.g., automation, digital surveillance, etc.) and generate efficiencies that aren't typically in the customer's best interests (e.g., transferring labour costs onto customers, etc.). These bureaucracies are often predatory, incompetent and fairly irrational (think here of British rail or the US health insurance industry). The customer is nothing but an unending revenue stream irrespective of service quality. And because there is little recourse to public watchdogs, extractive bureaucracies are often experienced as being worse than their governmental equivalents.

V.

The second mechanism that imbricates bureaucratisation with the neoliberal project, interwoven with the first, can be found in the workplace. Namely, the erosion of labour's position of power vis-à-vis employers. When the ideology of neoliberalism first entered the 
employment sphere in the early 1980s, the post-war social compromise between capital and labour was still relatively intact. In the US this was supported by the 1935 Wager Act, protecting the right to unionise and bargain at the national level. Similar arrangements could be found throughout the Western world. As Fordism began to flounder, however, employers discovered a new vocabulary to weaken labour's positional power. It sprung from the Chicago School and placed personal choice centre stage. Instead of employees having to conform to collective standards (e.g., regarding overtime, pensions, etc.) - often drafted and enforced by remote officials - they should be free to negotiate their own deals. Flexibility and individual preference were sold as 'empowerment' to workers, which US business gurus' labelled 'liberation management' in the 1990s, the arrival of a 'free agent nation'. ${ }^{35}$

Liberation management theorists repeatedly impugned bureaucracy. ${ }^{36}$ They claimed that Western capitalism was moribund because employers were tied to centralised agencies associated with the Wager Act, national union awards, labour arbitration courts, price controls, health and safety statutes, etc. Moreover, within firms themselves interminable red tape and pointless hierarchies had become a problem. Ford Motor Company was frequently cited as an example, which by the 1980s had managed to build twelve layers between executives and shopfloor workers. All decisions were centralised and vertical lines of communication had virtually ground to a halt. ${ }^{37}$

There's no doubt that such bureaucracies were important for controlling the labour process. However, as Richard Edwards saw in the late 1970s when studying corporations like IBM, General Electric and Polaroid, the use of job descriptions, career paths and procedures/regulations was also an outcome of labour struggles against the arbitrary rule of capital. ${ }^{38}$ Bureaucratic control had unwittingly given employees access to a new lexicon of rights and entitlements, exposing their otherwise isolated workplaces to collective struggles unfolding at the national and international level. In other words, bureaucracy had inadvertently politicised the workplace and risked radically democratising it to boot. ${ }^{39}$

With the elections of Ronald Reagan and Margret Thatcher, this never happened of course. Although the 'war' on bureaucracy was pitched as a push for improved individual freedom, it was obviously more about decollectivising the labour movement. Echoing F.A Hayek in particular ('freedom is seriously threatened today by the tendency of the employed majority to impose their standards and views of life on the rest'), the employment relationship was increasingly considered a private matter, where independent workers negotiate with their 
employer behind shut doors, far away from the prying eyes of the state..$^{40}$ Assisted by libertarian legalists like Richard A. Epstein, the proliferation of individual contracts was crucial to this decollectivisation process, which ironically bred its own impressive brand of (anti-collectivist) administration. ${ }^{41}$

The result was not increased prosperity for workers but the opposite. The celebration of isolated individualism in the employment relationship eroded security and wage levels, with contingent jobs and casualisation a predictable corollary. So why didn't bureaucracy disappear as predicted by neoliberal theory? An expression of administration actually did disappear, associated with the threat of mass democratisation that Richard Edwards mentioned. But it was swiftly rebuilt into a different sort of complex and a pretty nasty one at that. Labour economist David Gordon spotted early signs of this in the mid-1990s in his seminal study Fat and Mean. ${ }^{42}$ With the advent of US neoliberalism, statistical evidence reveals that the number of bureaucrats noticeably grew in the private sector, even after overall employment growth is taken into account. In 1948 administrative/supervisory staff made up 12 per cent of the workforce. The figure was nearly 20 per cent by 1992 .

Yet again, the size of this bureaucracy isn't the critical factor but its character when filtered through the prism of neoliberal reason. For example, take the attitude change that occurred when neoclassical economics was transposed into the workplace. Duff McDonald mentions this in his exposé of Harvard Business School and pernicious ideas like principle/agency theory that rose to prominence in the 1980s. ${ }^{43}$ Popularised by Chicago School-inspired business academics Michael Jensen and William Meckling, principle/agency theory was intended to predict management (mis)behaviour but was soon applied to everyone. ${ }^{44}$ Through this lens, 'agents' (workers, managers and even CEOs) are pegged as inveterate cash-hunting opportunists who will shirk their duties whenever they can. Employers (or 'principals') turned to invasive micromanagement to deal with the perceived threat.

In an ideological universe where shameless self-interest is king, this dark view of the workforce was probably inevitable. Paradoxically, it became especially evident when firms actually did try and adopt liberation management, trialling self-organising teams, decentralised decisionmaking, flat structures and information sharing. A classic example was documented by Shoshana Zuboff in her study of industrial digitalisation. ${ }^{45}$ When a large paper mill installed a computerised cost-tracking system (called ETS), the data was initially open to all employees. The company believed this transparency would help identify efficiency gains. Despite the 
impressive costs savings that accrued, management soon abandoned the policy and denied workers access to the information. Why so? They were afraid of what workers might do with the data: soon after, 'an abrupt escalation of bureaucracy that surrounded the ETS' ensued. ${ }^{46}$

Two important points follow. First, since neoclassical economists tell us that organisational members (workers, managers, etc.) can never be trusted to behave dutifully, supervisory bureaucracies will automatically expand, even in a context of labour market deregulation. As David Gordon observed, '... who keeps the supervisors honest? What guarantees that those supervisors won't be in cahoots with their charges? In such a hierarchy, you need supervisors to supervise supervisors... and the supervisors above them... and managers to watch the higher-level supervisors. ${ }^{2}{ }^{4}$

But this propagation doesn't take place in a vacuum, which brings us to the second point. What Gordon calls the 'stick strategy' of labour management mirrors the wider class structure, one that's been significantly destabilised and polarised in favour of employers. This explains why corporate managers are willing to tolerate costly bureaucracies rather than let workers organise the labour process themselves. For neoliberalism isn't simply an economic project, but a class one too and is happy to sacrifice efficiencies in order to keep that social relationship as onesided as possible. Hardnosed managerial bureaucracies are central to this.

As the relationship between capital and labour becomes increasingly lopsided, conflict is more likely. Hence why precarious and casualised work arrangements - perhaps the hallmark of neoclassical employment policy - attract so much management, charged with keeping a lid on the discontent. A recent European study of 3000 firms in deregulated labour markets (where 'flexible' jobs were extensively exploited) is telling in this respect. Given how workers are treated as independent contractors, it was assumed that employers would not need a great deal of administration. But that wasn't so:

we find that organisations employing high shares of flexible workers have higher shares of managers in their personnel... deregulated labour markets have thicker management bureaucracies than countries with more regulated labour markets of the "Rhineland" style. We argue that flexibility in labour markets (i.e. easier firing and higher labour turnover) damages trust, loyalty and commitment. This requires more management and control'. ${ }^{48}$

The implicit motto of managerialism today is clear: you're on your own (in terms of being responsible for your economic fortunes) but never left alone. 
VI.

The third mechanism pertains to the reorganisation of statecraft into a punitive process, one that tries to reconcile society with the partial interests of corporate and financial capital. The state didn't radically withdraw following the revitalisation of market fundamentalism in the 1980s, despite the 'small government' cant by Ronald Reagan, Bill Clinton and Milton Friedman. We instead witnessed a transformation of its modus operandi. As Duménil and Lévy explain regarding neoliberal governmentality in the 1980s, 'the creation of the new context of neoliberal globalisation was part of the deliberate objective of the states, which mirror those of the classes they represent' ${ }^{49}$

However, we must go further because this was no ordinary recontextualisation. The state aggressively sought to undo the post-war compromise and de-democratise the public sphere, which was now impeding the capital accumulation process. ${ }^{50}$ Bureaucracy is an understandable go-to tool for pursuing this objective, be it for administering regressive taxation policies or regulating the working poor. Furthermore, the sovereign debt crises following the 2008 financial meltdown provided an excellent cover-story for this predacious style of government, particularly in relation to welfare. ${ }^{51}$

The reformulation of the neoliberal state into a protectorate of big business can be seen in public spending figures. Look at the US and UK, for example. In 1980 the US spent 36.0 per cent as share of national GDP. ${ }^{52}$ In 2010 the figure was 45.07 per cent. The UK spent 52.5 per cent of GDP in 1980. In 2010 the figure was 53.45 per cent..$^{53}$ So where and how is the money spent? Certainly not on infrastructure, as crumbling bridges and sewers attest. Military expenditure is surely significant. But two spending targets standout. First, direct subsidies to private enterprise. For instance, it's been calculated that in 2015 the UK government transferred $£ 93$ billion to the business sector in this way (including subsidies, grants and corporate tax rebates), which overshadowed corporate tax revenues. ${ }^{54}$ Second - and oddly for stereotypical neoliberal economies - social spending related to unemployment benefits, family support, accommodation subsidies, food stamps, etc. In the US this figure rose from 12.48 per cent (in 1980) to nearly 20 per cent in 2010 and 15.54 per cent in the UK to 22.79 per cent in $2010 .{ }^{55}$

Doesn't this social spending defy the 'no handout' position of the austere neoliberal state? Not if we recall Hayek's qualifications regarding the permissible uses of state bureaucracy: 
there is little reason why government should not play some role, or even take the initiative, in such areas as social insurance and education... our problem here is not so much the aims but the methods of government action. ${ }^{56}$

The methods he prefers, of course, are those that extend commoditisation, even if it means subsiding private firms to do so: 'subsidies are a legitimate tool of policy, not as a means of income redistribution, only as a means for using the market to provide services'. ${ }^{57}$

Let's examine how this operates in Britain. Welfare spending subsidies the growing number of employers who refuse to pay a living wage in the fast food, service and retail sector, etc. For sure, UK workers born between 1981 and 2000 are now less-well off than old-age pensioners, and are the first generation to be poorer than their parents. ${ }^{58}$ The state bankrolls this incomedeficit so that 'liberalised' labour markets can continue unabated, costing $£ 11$ billion a year in tax credits and benefits. ${ }^{59}$ No wonder a soaring bureaucracy has emerged to manage these government programmes, manned by an army of officials who add insult to injury by monitoring its low-wage 'clients' and drowning them in senseless paperwork. ${ }^{60}$

Nonetheless, it's the character of this machinery rather than magnitude that matters. When it comes to the working poor and unemployed, the bureaucracies they encounter do not follow the dictum of 'without regard to person' that Max Weber spoke of, but are unusually vicious. Failed economic subjects - who are often the product of neoliberal policies - have to be punished in order for the credo of market individualism to appear credible. Treating them with compassion would imply there's something wrong with the system rather than the individual. For example, it was recently discovered that UK Jobcentre staff receive 'brownie points' for being cruel to their clients, reprimanding them for minor infringements. ${ }^{61}$ Then there's the notorious 'Fit for Work' scheme that medically reassesses ill beneficiaries with the aim of moving them back into the labour market. After being judged healthy enough, individuals receive a letter explaining why their payments will soon cease. An urgent appointment at the Jobcentre is then recommended (with calls costing $£ 0.55$ per minute, of course). In February 2019 this happened to 46-year-old Stephen Smith from Liverpool. The only problem was he had chronic obstructive pulmonary disease, osteoarthritis and used a colostomy bag. Incredibly, the Department of Work and Pensions (DWP) still rejected his appeal. Smith took the case to a tribunal and after seeing his emaciated, six stone body the judge immediately found in his favour. When 67 year-old Dawn Amos from Essex received her 'Fit for Work' letter she was 
already dead. Between December 2011 and February 2014 around 2,380 people died after being found fit for work by the DWP. ${ }^{62}$

Punitive state bureaucracies don't simply reflect the elite's distain for the poor. Two additional factors are at play. First, given widening class inequalities, the obscene redistribution of wealth to the rich and the social volatility that follows, it's unsurprising that redoubled efforts around policing/regulation is a priority for governments. ${ }^{63}$ And no matter how much public money is spent, it can always be made compatible with neoliberalism's 'rule of law' datum or what Hayek calls 'limited security', a sliding scale no doubt. ${ }^{64}$ Second, punitive bureaucracies convey a basic loathing of the public sphere. This is apparent in how its workers are treated. State organisations now behave like hungry business enterprises, exploiting their workers as private capital does theirs, deploying an array of metrics and key performance indicators to do so. A lot of bureaucracy is needed for this. Hence why the neoliberal university, for example, doesn't conform to the 'lean and mean' cliché found in kindergarten evocations of neoclassical economics. Yes, they've been commercialised and exposed to market forces. But that's actually made them fatter and mean, overcrowded with hostile administrators who generally despise academics, as the 2018 UK pensions dispute revealed. ${ }^{65}$

Once again, it's tempting to think that F.A Hayek would frown with disapproval if he could survey the immense state bureaucracies supporting (and acting like) the business world today. But realistically, he'd probably just shrug.

VII.

In summary, it appears that the abstractions of neoliberal orthodoxy cannot function in the real world without a certain mode of administration. The disjunction is quietly resolved in the writings of F.A Hayek inter alia. Certain provisos in an otherwise unyielding interpretation of market fundamentalism permits the presence of muscular business-centric states and vast corporate bureaucracies. I have also identified three mechanisms that realise this synthesis. In the business sphere, the centralisation and concentration of corporate and financial capital; in the employment sphere, the demise of the capital/labour compact and a renewed emphasis on bureaucratic hierarchies to control workers; and in the state sphere, public administration being recast as an punitive warden of society, managing the class antagonisms that arise when financial capitalism is handed the keys to the house.

No doubt the term 'neoliberalism' is overused today. It is ascribed to anything negatively associated with contemporary capitalism, no matter how far or wide. ${ }^{66}$ Some even claim that 
its star is now fading following Brexit and a resurgence in ethno-nationalism, which is debateable. Regardless, the effects of this economic doctrine are writ large almost everywhere and a specific style of bureaucratisation is chief among them. We can now appreciate how neoliberal praxis is fairly congruent with complex and overbearing administrative structures in the public and private sector. Rather than signalling a rejection of neoliberalism, perhaps the recent appearance of state-sponsored authoritarian capitalism is but an elaboration of the caveats buried deep in the works of F.A Hayek and fellow travellers.

In light of our analysis, the classic Weberian demarcation between formal-instrumental rationality (Zweckrational or technical 'means') and substantive reason (Wertrational or valuebased 'ends') looks problematic. ${ }^{67}$ Bureaucracy under neoliberalism shouldn't be viewed as a neutral machine that's been hijacked by errant powerholders, since that would imply the same apparatuses could simply be attached to friendlier, more progressive governance strategies. But as Hayek intimates, the administrative means themselves undergo a qualitative transformation when charged with forceful political ends. I think this accounts for the highly normative and malign texture of the bureaucracies examined above (and we could add many other examples, including the intimidating 'expulsive bureaucracies' associated with immigration). Hardly paragons of neutrality and pretty much non-transferable to any future emancipatory undertaking. Therefore, successfully opposing the present economic regime will necessarily entail radically rethinking the daily means through which any coming polity is administered. Not only the 'big picture' but the smallest one too.

\section{NOTES}

${ }^{1}$ See Philip Mirowski, 'Postface: Defining Neoliberalism' in Philip Mirowski and Dieter Plehwe (eds) The Road to Mont Pelerin: The Making of the Neoliberal Thought Collective, Cambridge MA, Harvard University Press, 2009; William Davies, The Limits of Neoliberalism: Authority, Sovereignty and the Logic of Competition, London, Sage, 2017.

${ }^{2}$ David Graeber, The Utopia of Rules: On Technology, Stupidity, and the Secret Joys of Bureaucracy, New York, Melville House, 2016, pp42.

${ }^{3}$ Beatrice Hibou, The Bureaucratization of the World in the Neoliberal Era: An International and Comparative Perspective, Trans. Andrew Brown, New York, Palgrave Macmillan, 2015.

${ }^{4}$ Max Weber, Economy and Society: An Outline of Interpretive Sociology, Trans. G. Roth \& C. Wittich, Berkeley, University of California Press, 1978.

${ }^{5}$ Max Weber, From Max Weber: Essays in Sociology, Trans. H. Girth and C. Wright Mills, New York, Oxford University Press, 1946.

${ }^{6}$ In this respect, David Graeber is mistaken when he claims 'a left critique of bureaucracy ... is sorely lacking' (ibid, pp44). For an early example see Herbert Marcuse, 'Some Social 
Implications of Modern Technology' in Arato, Andrew and Eike, Gebhardt (Eds), The Essential Frankfurt School Reader. New York, Continuum, 1941/1982, pp138-162.

${ }^{7}$ Herbert Marcuse, One-Dimensional Man: Studies in the Ideology of Advanced Industrial Society, Boston, Beacon Press, 1964/1991, pp32.

${ }^{8}$ David Harvey, A Brief History of Neoliberalism, Oxford, Oxford University Press, 2005, pp2.

${ }^{9}$ James Kenneth Galbraith, The Predator State: How Conservatives Abandoned the Free Market and Why Liberals Should Too, New York, Free Press, 2008, pp19.

${ }^{10}$ Friedrich A. Hayek, The Road to Serfdom, London, Routledge, 1944; Ludwig von Mises, Bureaucracy, New Haven, Yale University Press, 1944.

${ }^{11}$ Daniel Guérin argued that German and Italian fascism was a capitalist response to economic crisis, with heavy industry, land owners and banks opting for a 'closed commercial state' to shore up their interests during mass unrest. Daniel Guérin, Fascism and Big Business, Trans. F. and M. Merr, New York, Pathfinder Books, 1938/1973, pp77-78.

${ }^{12}$ Friedrich A. Hayek, Law, Legislation, Liberty: A New Statement on the Liberal Principles of Justice and Political Economy, Vol. 2, London, Routledge, 1976, pp108-109.

${ }^{13}$ Hayek, The Road to Serfdom, pp242.

${ }^{14}$ Friedrich A. Hayek, The Road to Serfdom: The Condensed Reader's Digest Version, London. Institute of Economic Affairs, 1945/2005, pp41.

${ }^{15}$ Friedrich A. Hayek, The Constitution of Liberty, Chicago, Chicago University Press, 1960, pp331.

16 ibid., pp334.

${ }^{17}$ Hayek believed European federation would force individual nation-states to compete for investment and dismantle obtrusive regulations in the process, including child labour restrictions: "provided the state could not exclude commodities produced in other parts of the Union, any burden placed on a particular industry by state legislation would put it at a serious disadvantage as opposed to similar industries in other parts of the Union. As has been shown by experience in existing federations, even such legislation as the restriction of child labor or of working hours becomes difficult to carry out for the individual state.' F.A. Hayek, Individualism and Economic Order, Chicago, Chicago University Press, 1939/1948, pp260.

${ }^{18}$ Quoted in John M Geddes, 'New Vogue for Critics of Keynes', New York Times, May 7, 1979, D1.

${ }^{19}$ Hayek, The Constitution of Liberty, pp382

20 'What is increasingly suspending the working of spontaneous forces of the market are not what the public have in mind when it complains about monopolies, but the ubiquitous associations and unions of various trades'. Friedrich A. Hayek, Law, Legislation, Liberty: A New Statement on the Liberal Principles of Justice and Political Economy, Vol. 3. London, Routledge, 1979, pp89.

${ }^{21}$ Steve Hilton, More Human: Designing a World Where People Come First, New York, W. H. Allen, 2015.

22 ibid, pp183.

${ }^{23}$ Von Mises, Bureaucracy, pp64.

${ }^{24}$ Marx foresaw it as a logical outcome of capitalism because in order to control commodity prices and increase surplus value firms must absorb competitors. This was subsequently demonstrated by V.I. Lenin (which he aligned with imperialism), Austrian economist Rudolf Hilderding and later in the 1960s by Paul Sweezy and Paul Baran in the US.

${ }^{25}$ See John Bellamy Foster and Robert McChesney, The Endless Crisis: How MonopolyFinance Capital Produces Stagnation and Upheaval From the USA to China, New York, Monthly Review Press, 2012.

${ }^{26}$ Vitali, S, Glattfelder, J.B and Battiston, S (2011). 'The Network of Global Corporate Control'. Zurich: Federal Institute of Technology. 
${ }^{27}$ Jordan Brennan, 'Rising Corporate Concentration, Declining Trade Union Power, and the Growing Income Gap: American Prosperity in Historical Perspective', Levy Economics Institute at Bard College, Annandale-on-Hudson, 2016.

${ }^{28}$ Frank Knight, 'Conflict of Values: Freedom and Justice' in Goals of Economic Life, Alfred Dudley Ward (Ed), New York, Harper and Brothers, 1953, pp224-25.

${ }^{29}$ Milton Friedman, 'Milton Friedman on business suicide'. The Cato Institute. March/April, 1999.

${ }^{30}$ The sleight of hand permits libertarians like Richard A. Epstein to simultaneously denounce labour unions as nefarious cartels and happily justify corporate monopolies due to the 'social premium' they yield. See Richard A. Epstein, 'Justified Monopolies: Regulating Pharmaceuticals and Telecommunications,' Case Western Reserve Law Review, 103 (2005): 103-134.

${ }^{31}$ A few examples include Rudolf Hilderding, Finance Capital: A Study of the Latest Phase of Capitalist Development, Edited by Tom Bottomore, London Routledge and Kegan Paul, 1910/1981; Reinhardt Bendix, Work and Authority in Industry, Berkeley, University of California Press, 1956; Harry Braverman, Labor and Monopoly Capital: The Degradation of Work in the Twentieth Century, New York, Monthly Review Press, 1974 and Earnest Mandel, Power and Money: A Marxist Theory of Bureaucracy, London, Verso, 1992.

${ }^{32}$ Alfred Chandler, The Visible Hand: The Managerial Revolution in American Business. Cambridge, MA, Harvard University Press, 1977.

${ }^{33}$ This has also be termed 'managerial capitalism'. See Gerard Duménil and Dominique Lévy, Managerial Capitalism: Ownership, Management and the Coming New Mode of Production, London, Pluto, 2018.

${ }^{34}$ Gerard Hanlon, The Dark Side of Management: A Secret History of Management Theory London, Sage, 2015.

35 Tom Peters, Liberation Management: Necessary Disorganization for the Nanosecond Nineties, New York, Alfred A. Knopf, 1992; Daniel Pink, Free Agent Nation: The Future of Working for Yourself, New York, Hachette Book Group, 2002.

${ }^{36}$ And still is. For a recent example see Gary Hamel, 'Why Bureaucracies Must Die', Fortune, 2014, available at http://fortune.com/2014/03/26/why-bureaucracy-must-die/.

${ }^{37}$ See Michael Perelman, The Invisible Handcuffs of Capitalism: How Market Tranny Stifles the economy by Stunting Workers, New York, Monthly Review Press, 2011.

${ }^{38}$ Richard Edwards, Contested Terrain: The Transformation of the Workplace in the Twentieth Century, New York, Basic Books, 1979.

${ }^{39}$ Edwards notes, 'bureaucratic control thus established an explicit structure around which broader struggles in the political arena coalesce. These struggles provide and immediate avenue for improving the contradictions of wage labor, and they may have more revolutionary consequences by linking workplace struggle with class conflict in society at large... by constructing formal rights and responsibilities, capitalists have abolished the individual capitalist's responsibility for working conditions and replaced it with a social accountability'. Ibid, pp162.

${ }^{40}$ Hayek, The Constitution of Liberty, pp186.

${ }^{41}$ See Richard A. Epstein, 'In Defense of the Contract at Will', University of Chicago Law Review, 51 (1984), 947-982; Richard A. Epstein, Forbidden Grounds: The Case Against Employment Discrimination Laws, Cambridge MA, Harvard University Press, 1992.

${ }^{42}$ David Gordon, Fat and Mean: The Corporate squeeze of Working Americans and the Myth of Managerial "Downsizing”, New York, Free Press, 1996.

${ }^{43}$ Duff McDonald, D, The Golden Passport: Harvard Business School, the Limits of Capitalism and the Moral Failure of the MBA Elite, New York, Harper, 2017. 
${ }^{44}$ See Michael Jensen and William Meckling, 'Theory of the Firm: Managerial Behavior, Agency Costs and Ownership Structure', Journal of Financial Economics, 3, 4 (1977): 305360

${ }^{45}$ Shoshana Zuboff, In the Age of the Smart Machine: The Future of Work and Power, New York, Basic Books, 1989.

${ }^{46}$ Ibid, pp263.

${ }^{47}$ Gordon, Fat and Mean, pp40

48 Alfred Kleinknecht, Zelin Kwee and Lilyana Budyanto, 'Rigidities through flexibility: flexible labour and the rise of management bureaucracies', Cambridge Journal of Economics, 40, 4, (2016), 1137-1147, pp1137.

${ }^{49}$ Gerard Duménil and Dominique Lévy, The Crisis of Neoliberalism, Cambridge, MA, Harvard University Press, 2011, pp88.

${ }^{50}$ Wolfgang Streeck, Buying Time: The Delayed Crisis of Democratic Capitalism. Trans. P. Camiller, London, Verso, 2014.

${ }^{51}$ Mark Blyth, Austerity: The History of a Dangerous Idea, New York, Oxford University Press, 2015.

52 Paolo Mauro, Rafael Romeu, Ariel Binder and Asad Zaman, 'A modern history of fiscal prudence and profligacy’, Journal of Monetary Economics, 76 (2015), 55-70.

${ }^{53}$ Ibid.

54 Aditya Chakrabortty, 'The £93bn handshake: Businesses pocket huge subsidies and tax breaks', The Guardian, 2015, Available at https://www.theguardian.com/politics/2015/jul/07/corporate-welfare-a-93bn-handshake

55 Esteban Ortiz-Ospina and Max Roser, 'Government Spending', Our World in Data, 2018, Available at https://ourworldindata.org/government-spending

${ }^{56}$ Hayek, The Constitution of Liberty, pp374.

${ }^{57}$ Ibid, pp379. Indeed, even Milton Friedman would eventually agree, most notably when he proposed a negative income tax when literacy rates were questioned following school deregulation. The IRS - which Friedman thought epitomised big government - could be repurposed to fuel the market system, effectively turning welfare into a business opportunity.

${ }^{58}$ Daniel Tomlinson and Fahmida Rahmam, 'Cross countries: International Comparisons of Intergenerational Trends', Resolution Foundation, 2019, Available at https://www.resolutionfoundation.org/publications/cross-countries-international-

comparisons-of-intergenerational-trends/

59 Citizens UK, 'The Public Subsidy to Low Wage Employers', 2015, Available at https://www.citizensuk.org/subsidy report

${ }^{60}$ Relating to the UK, see Ivor Southwood, Non-Stop Inertial, London, Zero Books, 2011.

With respect to US welfare programmes, see Pamela Herd and Donald P. Moynihan,

Administrative Burden: Policy Making by Other Means, New York, Russell Sage Foundation, 2018.

${ }^{61}$ Mary O'Hara, 'As a Jobcentre Adviser, I got “Brownie Points” for Cruelty', The Guardian, 2015, available at https://www.theguardian.com/society/2015/feb/04/jobcentre-adviser-playbenefit-sanctions-angela-neville

${ }^{62}$ Department for Work and Pensions, 'Mortality Statistics: Employment and Support

Allowance, Incapacity Benefit or Severe Disablement Allowance', Westminster, London, 2015.

${ }^{63}$ It was only a matter of time before digital algorithms were employed for this objective, as illustrated by the ongoing 'robo-debt' controversy in Australia. The agency responsible for welfare - Centrelink - implemented an automated datamatching system to issue thousands of debt-recovery letters to beneficiaries. Mistakes, miscalculations and the callous method of 
delivery caused much distress and anxiety a public inquiry found. Commonwealth of Australia, 'Community Affairs references Committee - Better Management of the Social Welfare System Initiative', 2017, available at https://parlinfo.aph.gov.au/

${ }^{64}$ Hayek, The Constitution of Liberty, pp376.

${ }^{65}$ Times Higher Education, 'Academics in the minority at more than two-thirds of UK universities', September 3, 2015.

${ }^{66}$ See Rajesh Venugopal, 'Neoliberalism as a Concept'. Economy and Society, 44 (2): $165-$ 187, 2015.

${ }^{67}$ This problem has been debated for years. It partly stems from Weber's conceptual reliance on 'ideal-types' or typological 'mental images' (Gedankenbilder) that aspire to ethicalneutrality. Furthermore, the influence of Tacitus and Machiavelli undoubtedly encouraged a detached view of the bureaucratic 'means' vis-à-vis the subjective 'ends' that shifting powerholders pursue. We might call this the 'levers of power' approach to domination. Through this lens Weber can comfortably argue, for instance, 'the state itself has no intrinsic value in that it is purely a technical instrument for the realization of other values ...' Max Weber, Methodology of Social Sciences, Trans Edward A. Shils and Henry A. Finch, Chicago, Free Press, 1949, pp47. 